\title{
The Uses of Violence
}

\author{
Michael Bernhard and Daniel O'Neill
}

\section{Considering Violence}

$T$

he vast majority of content in this issue addresses violence. In its many forms it has been central to the study of politics from ancient times, and to the discipline of political science from its inception. Physical coercion is one of the most common means by which power is exercised, along with material and moral forms of suasion (Etzioni 1971, 357-59). For Weber, coercion and material calculus are the means by which authority can be enforced when rulers cannot establish legitimacy (Weber 1978, 214). Violence is essential to the exercise of power and enforcement of political order. However, when it is turned against powerholders it can also be a means to overturn existing relations of power and patterns of order. Of course, it is not the only means to do so, and nonviolent forms of resistance have been shown to be as effective, or even more so, in many contexts (Sharp 1973; Chenoweth and Stephan 2011).

On a micro-level, the effects of violence have been demonstrated to be highly deleterious to human beings well beyond the obvious proximate physical effects. It brings trauma that stays with the individuals subjected to it, and often those who inflict it, for the rest of their lives, and its negative effects may continue to impact future generations (Browning 1992; Lifton 1968, 1973, 1986).

Still there are some political theorists who argue that violence has a cathartic role in overcoming the effects of degrading and demeaning aspects of unjust rule. This was influentially articulated by the syndicalist Georges Sorel in his Reflections on Violence (1961 [1908]) and was taken up as a kind of cult practice by the interwar far-right (Mann 2004). Frantz Fanon, one of the most influential theorists of national liberation in the postwar era, also discussed the use of violence as a means to shake off the degrading effects of colonialism (1961).

The short-term effects of violence from a macroperspective are almost universally negative. Destruction of property and loss of life have negative impacts on welfare and economic progress. In comparison to nonviolent protest, violent protest is much more dangerous for democratic rule (Teorell 2010; Celestino and Gledistch 2013; Bayer, Bethke, and Lanbach 2016). However, from a more distal perspective violence can lead to changes in structural conditions that represent barriers to economic, political, and social change. Here we are not talking about some sort of purposive social engineering but the unintended consequences of large-scale violence. Once unleashed, there is no telling what its epiphenomenal effects might be. Barrington Moore notes this in his discussion of the origins of Western liberal democracy: "The Revolt of the Netherlands, the Puritan Revolution, the French Revolution, and the American Civil War did help to break down in each case a different historical set of institutional obstacles to the establishment of Western liberal democracy, though it is of course impossible to prove that they were necessary to bring about this result" $(1969,6)$.

Violence was intrinsic to these processes, which in retrospect we see as forms of progress. Similarly, it took the military defeat of Nazism, and the partition of Germany between East and West to break German traditions of militarism, reaction, and the Iron and Rye political economy that impeded the emergence of stable democracy (Bernhard 2001). The ramifications of this for the relative peace and stability in Europe since 1945 are critical.

In Sheri Berman's recent work (discussed in this issue in a Critical Dialogue with Daron Acemoglu and James Robinson), the emergence of democracy is depicted as a process through which remnants of the ancien régime are dismantled and replaced by modern, competitive, and more politically egalitarian forms of rule. In France it took almost one hundred years, four revolutions, and defeat in major war before the old regime was sufficiently weakened to permit the emergence of a durable democracy. The first attempt at democratic rule failed during the Revolution of 1789 , and it took the defeat of Bonaparte in the first European global war, the Revolutions of 1830 and 1848, the defeat in the Franco-Prussian War, and the failure of the Paris commune before the competitive system of government of the French Third Republic, based only on universal male suffrage, was stabilized by the Constitution of 1875 (Berman 2019, ch. 6; Hanson 2010, ch. 4).

Still, one does not create progress by design through violence, and we should rightly be skeptical of those who propose such a thing. Violence has large-scale and widereaching consequences and, under a fortuitous set of 
circumstances, those consequences can remove obstacles to the emergence of novel forms of rule like democracy. This is not always the case, of course. Other massively violent episodes such as the imposition of Western colonialism have left countries with long-term legacies that have yielded highly exploitative extractive economic orders that promote dictatorial rule (Kohli 2020). And sometimes colonialism and imperialism have, indeed, been successfully defeated by violent means, although this, too, has never been pretty.

\section{The Special Section}

The articles that compose our special section on the uses of violence are decidedly not in this macro-perspective. Many of them, though, capture microlevel countermovements made in reaction to progress. From a macro-level perspective, episodes of democratic progress often result in the diminution of the inherited privileges of the past as well as full incorporation of newly empowered populations previously excluded from the full benefits of citizenship. This helps explain why the construction of stable democratic systems is so difficult and time-consuming. Moreover, episodes of progress in turn lead to episodes of backlash where social forces whose privilege was erased by democratic progress attempt to reassert their prerogative power.

Several pieces in this issue show how violence has been used by traditional authorities in an attempt to reassert their domination over parts of the population that have successfully weakened those bonds. Backlash of this sort in the United States has been directed most recently at women, African Americans, and immigrants.

Two of our articles examine the uses of violence in support of misogyny. In "The Cost of Doing Politics? Analyzing Violence and Harassment against Female Politicians," Mona Lee Krook and Juliana Restrepo Sanín produce an innovative typology that allows us to conceptualize five different forms of violence used to marginalize female politicians: physical, psychological, sexual, economic, and semiotic. In her contribution, "Public Emotions and Variations of Violence," Stacey Hunt probes the reasons behind an outbreak of acid attacks against women in Colombia. She explores the affective economy of consumption and desire for explanations of Colombia's history of violence, and links ideas that explain its persistence as a misunderstood passion for the beauty of women to this startling upsurge in disfiguring intimate violence.

Turning to race, it is important to note that despite the abolition of slavery more than 150 years ago, every attempt to secure African American equality since then has been met with counter-movements that attempt to both maintain and transform white supremacy. Abolition and reconstruction were countered by segregation, Jim Crow, and lynching, and the successes of the civil rights movement with the carceral state and voter suppression. Three pieces in the special section examine the racist uses of violence to confine African Americans to a persistent status as second-class citizens. In "Rule by Violence, Rule by Law: Lynching, Jim Crow and the Continuing Evolution of Voter Suppression in the U.S.," Brad Epperly, Christopher Witko, Ryan Strickler, and Paul White discuss the conditions under which the suppression of African-Americans has been carried out by legal as opposed to violent means. They illustrate its utility for white racists with illustrations from the postreconstruction era and the contemporary wave of voter suppression in the United States. In "The Strange Fruit of the Tree of Liberty: Lynch Law and Popular Sovereignty in the United States," Michael Gorup explores how and why lynchings of African Americans in front of large crowds were central to the construction of a racialized notion of "the people" in America. Gorup argues that through the violent public spectacle of lynching, popular sovereignty in the United States was arrogated exclusively to white people, while African Americans were constituted as second-class citizens and social subordinates.

The third piece addressing the role of violence in race relations assesses its impact on African American political consciousness and behavior. In "Reconceptualizing Political Knowledge: Race, Ethnicity, and Carceral Violence," Cathy J. Cohen and Matthew D. Luttig show that carceral state violence leads to fundamental differences in what constitutes political knowledge for black and white Americans. The results of simplistic tests that show whites to be more politically knowledgeable than blacks are reversed when questions on carceral violence are included in such tests. Furthermore, Cohen and Luttig also show that those who have the greatest knowledge of carceral violence are less likely to participate in politics, demonstrating that the repressive and disempowering impact of the carceral state goes well beyond the daily indignities of aggressive policing and the harsher punishments received by African Americans.

Our final piece on repressive backlash turns to religious prejudice with a focus on the recent increase in violence against American Jews. Using the FBI's data on religious hate crime, Ayal Feinberg determines which conditions promote the targeting of American Jews in "Explaining Ethnoreligious Minority Targeting: Variation in U.S. Anti-Semitic Events." He focuses on four areas: target concentration, target distinguishability, number of hate groups, and stimuli that increase target salience. He finds that hate crimes directed against Jews are concentrated where there are large numbers of Jews and hate groups, where Jewish populations are less assimilated and thus distinguishable from the population at large, and in response to triggering events like Israeli military action.

The diversity of our selections for the special section points to other uses of violence beyond backlash. Eduardo Moncada's “The Politics of Criminal Victimization: Pursuing and Resisting Power" reminds us that 
violence is inscribed in class relations as well as race and gender relations or religious hatred. Violence has also long served as a means to expropriate value from vulnerable populations. Using intensive fieldwork among informal street vendors in large Latin American cities, Moncada sheds light on the resistance behaviors adopted by vendors in response to expropriation of their earnings by organized protection rackets. He reminds us that violence is not always an effective means to exercise power, and this is often the result of the ingenuity of those subjected to it in avoiding its pernicious effects.

One of our selections addresses the potential liberating effects of violence along the lines discussed at the outset of this introduction. Güneş Murat Tezcür examines the Kurdish insurgency in Syria and the role of women fighters there in "A Path Out of Patriarchy? Political Agency and Social Identity of Women Fighters." Based on a novel dataset containing information on 9,000 militants and a host of in-depth interviews, the study finds that mobilization into the ethnic insurgency was a pathway for uneducated Kurdish women to escape the bonds of patriarchal domination. Whether this effect will be permanent or temporary, especially given uncertainty about the outcome of the struggle, has yet to be determined.

Our last selection looks at how the depiction of violence in media impacts our attitudes towards it. In "Wait, There's Torture in Zootopia? Examining the Prevalence of Torture in Popular Movies," Casey Delehanty and Erin Kearns look at depictions of torture and its effectiveness in popular American motion pictures from 2008 to 2017. They raise the issue of whether this depiction has helped to legitimize torture in American popular culture. The inclusion of torture in major motion pictures is ubiquitous, even in movies for children, and it is overwhelmingly depicted as effective. Furthermore, it is presented in a starkly Manichean fashion, where movie protagonists only rely on torture as a last-minute measure to avoid deadly threats, and their antagonists use it to target innocent victims or to punish their opponents.

\section{Other Content}

In this issue we also include Alexander Livingston's article "Tough Love: The Political Theology of Civil Disobedience," which focuses on the early development of Martin Luther King's commitment to "aggressive love." This approach brought the uses of non-violence, rather than violence, to the fore of the discussion on how to achieve political ends. Livingston locates the origins of this concept in black theologians' engagement with Indian anticolonialism and traces its particularistic development through King's early Civil Rights activism. For Livingston, King's commitment to responding to oppression with aggressive love illustrates a crucial, if paradoxical dimension of civil disobedience: the importance of affirming civility while enacting non-violent resistance, thereby fusing political confrontation together with a commitment to political pedagogy.

The research content of the issue closes with a provocative reflection from Jack Goldstone and Larry Diamond. In "Global Demographic Change and the Future of Democracy," they ponder the combined impact of demographic stagnation in advanced democratic states and large-scale population growth in Central America, subSaharan Africa, and the Middle East. They argue that these twin developments have had adverse effects on democracy globally. The combination of poor economic performance, climate change impacts, and bad governance in the latter has led to waves of asylum seekers to the economically wealthy democracies. This wave of immigrants from new areas of the globe has provoked anxiety, resurgent nationalism, and support for populist strong men in the former. Goldstone and Diamond stress the importance of demographic stability, good governance, and the creation of economic opportunity in developing regions of the globe as the solution to creating a more democratic and stable future in both regions.

\section{A Journal in the Plague Year}

Perspectives on Politics continues to publish, though we do so under a set of challenging conditions brought about by the coronavirus global pandemic. The print edition of the journal is suspended due to disruptions beyond the control of Cambridge University Press. Instead, both they and we will focus on the online edition.

Normal processing of manuscripts continues, although the number of submissions has slowed somewhat. This usually happens at the end of the spring semester when academics concentrate on writing and grading finals and transitioning to research mode in the summer months. We will know more about the pandemic's effects in the coming months when we see if submissions pick up as usual.

It is perhaps fortuitous that we find ourselves in a submission lull, as it is more difficult to find reviewers these days. Many of us have had to make abrupt transitions to on-line teaching, and those of us with school-age children face a greater burden of care and in some cases schooling. We are fully cognizant of these challenges, and their gendered dimensions, and understand why many colleagues cannot take on assignments at this time and are more prone to be a bit late in completing them. Thus, if you submit, please be patient with us; things operate a bit slower in a plague year.

Our biggest challenges come on the book review side of the journal. The disruption of global supply chains means that many of the big publishing houses are no longer shipping hard copies of books. We know that many reviewers prefer to work with them, but when our current inventory is assigned, we may have to work with electronic versions of the books. Our current stock will take us through 
the end of the present volume (for the 2020 calendar year) and maybe a bit beyond. This supply chain breakdown complicates our task in selecting books for review. And, as on the article side of the journal, it is a bit harder to find reviewers. The authors of book reviews face the same set of challenges we all do in terms of finding new ways to work in a timely and effective fashion. Thus, we ask for your understanding and patience with the book review section. We will do everything we can to prevent the number of books reviewed from falling off precipitously, and to ensure the timeliness of those reviews insofar as we are able.

We are committed to keeping the operation of the journal as normal as possible through the uncertainty of the current crisis and what comes next. We are very fortunate to have the backing of well-run organizations like the American Political Science Association, Cambridge University Press, and the University of Florida. As academics, we need to acknowledge our privileged position in our current cataclysm. Most of us who are tenured or on tenure-track lines continue to draw our salaries, and much of what we do is conducive to on-line delivery that allows us to practice physical distancing. We need to be conscious of this and do what we can to help colleagues in our discipline who do not have permanent employment, graduate students who face uncertain job prospects, and undergraduates who find themselves in precarious situations because of the economic ramifications of the pandemic. Finally, we need to acknowledge that while the pandemic is striking fellow human beings of all nations and social classes, in our country the highest toll is being paid by those who do not share our privilege, specifically minority populations in our large urban centers, as well as those who continue to provide "essential" service work, especially those who do so for modest pay. And, as ever, the burden of increased care work in response to the pandemic often falls disproportionately on the basis of gender. This situation exists precisely because of the kind of violent backlash against progress that many of the authors in the special section discussed earlier illuminate for us.

\section{References}

Bayer, Markus, Felix S. Bethke, and Daniel Lambach. 2016. "The Democratic Dividend of Nonviolent Resistance." Journal of Peace Research 53(6): 758-61.
Berman, Sheri. 2019. Democracy and Dictatorship in Europe: From the Ancien Régime to the Present Day. Oxford: Oxford University Press.

Bernhard, Michael. 2001. "Democratization in Germany: A Reappraisal." Comparative Politics 33(4): 379-400.

Browning, Christopher R. 1992. Ordinary Men: Reserve Police Battalion 101 and the Final Solution in Poland. New York: Harper Collins.

Celestino, Mauricio Rivera, and Kristian Skrede Gleditsch. 2013. "Fresh Carnations or All Thorn, No Rose? Nonviolent Campaigns and Transitions in Autocracies." Journal of Peace Research 50(3): 385-400.

Chenoweth, Erica, and Maria J. Stephan. 2011. Why Civil Resistance Works: The Strategic Logic of Nonviolent Conflict. New York: Columbia University Press.

Etzioni, Amitai. 1971. The Active Society. New York: Free Press.

Fanon, Frantz. 1961. The Wretched of the Earth. New York: Grove Weidenfeld.

Kohli, Atul. 2020. Imperialism and the Developing World. New York: Oxford University Press.

Hanson, Stephen. 2010. Post-Imperial Democracies: Ideology and Party Formation in Third Republic France, Weimar Germany, and Post-Soviet Russia. Cambridge: Cambridge University Press.

Lifton, Robert J. 1968. Death in Life: Survivors of Hiroshima. New York: Random House.

- 1973. Home from the War: Vietnam VeteransNeither Victims nor Executioners. New York: Simon \& Schuster.

- 1986. The Nazi Doctors: Medical Killing and the Psychology of Genocide. New York: Basic Books.

Mann, Michael. 2004. Fascists. Cambridge: Cambridge University Press.

Moore, Barrington. 1969. Reflections on the Causes of Human Misery and Upon Certain Proposals to Eliminate Them. Boston: Beacon.

Sharp, Gene. 1973. The Politics of Nonviolent Action. 3 vol. Boston: Porter Sargent.

Sorel, Georges. 1961. Reflections on Violence. New York: Collier Books.

Teorell, Jan. 2010. Determinants of Democratization: Explaining Regime Change in the World, 1972-2006. New York: Cambridge University Press.

Weber, Max. 1978. Economy and Society. 2 vol. Berkeley: University of California Press. 


\section{Statement of Mission and Procedures}

Perspectives on Politics seeks to provide a space for broad and synthetic discussion within the political science profession and between the profession and the broader scholarly and reading publics. Such discussion necessarily draws on and contributes to the scholarship published in the more specialized journals that dominate our discipline. At the same time, Perspectives seeks to promote a complementary form of broad public discussion and synergistic understanding within the profession that isessential toadvancing scholarship and promoting academic community.

Perspectives seeks to nurture a political science public sphere, publicizing important scholarly topics, ideas, and innovations, linking scholarly authors and readers, and promoting broad reflexive discussion among political scientists about the work that we do and why this work matters.

Perspectives publishes work in a number of formats that mirror the ways that political scientists actually write:

Research articles: As a top-tier journal of political science, Perspectives accepts scholarly research article submissions and publishes the very best submissions that make it through our double-blind system of peer review and revision. The only thing that differentiates Perspectives research articles from other peer-reviewed articles at top journals is that we focus our attention only on work that in some way bridges subfield and methodological divides, and tries to address a broad readership of political scientists about matters of consequence. This typically means that the excellent articles we publish have been extensively revised in sustained dialogue with the editors to address not simply questions of scholarship but questions of intellectual breadth and readability.

"Reflections" are more reflexive, provocative, or programmatic essays that address important political science questions in interesting ways but are not necessarily as systematic and focused as research articles. These essays often originate as research article submissions, though sometimes they derive from proposals developed in consultation with the editor in chief. Unlike research articles, these essays are not evaluated according to a strict, doubleblind peer review process. But they are typically vetted informally with editorial board members or other colleagues, and they are always subjected to critical assessment and careful line-editing by the editor and editorial staff.

Scholarly symposia, critical book dialogues, book review essays, and conventional book reviews are developed and commissioned by the Associate and Book Review Editor, based on authorial queries and ideas, editorial board suggestions, and staff conversations.

Everything published in Perspectives is carefully vetted and edited. Given our distinctive mission, we work hard to use our range of formats to organize interesting conversations about important issues and events, and to call attention to certain broad themes beyond our profession's normal subfield categories.

For further details on writing formats and submission guidelines, see our website at http://www.apsanet.org/ perspectives/ 